\title{
Interferon-induced depression in patients with hepatitis C: an epidemiologic study
}

Lucas Pereira Jorge de Medeiros ${ }^{1,2,3}$, Monica Kayo ${ }^{4}$, Renata Barboza Vianna Medeiros ${ }^{5}$, Mario Barreto Correa Lima ${ }^{1}$ Carlos Eduardo Brandão Mello ${ }^{1,5}$

${ }^{1}$ Federal University of the State of Rio de Janeiro (UNIRIO), Rio de Janeiro, RJ, Brazil

${ }^{2}$ Souza Marques Medical School, Rio de Janeiro, RJ, Brazil

3University Center of Volta Redonda, Volta Redonda, RJ, Brazi

"University of São Paulo, School of Medicine (FMUSP), São Paulo, SP, Brazil

${ }^{5}$ Federal University of Rio de Janeiro (UFRJ), Rio de Janeiro, RJ, Brazil

Study conducted in the Federal University of the State of Rio de Janeiro (UNIRIO), Rio de Janeiro, RJ

Article submitted: 10/04/12 Accepted for publication: 06/30/13

Correspondence: Santa Casa de Misericórdia do Rio de Janeiro

Rua Jardim Botânico, 656/405 Jardim Botânico ZIP Code: 22461-010

Rio de Janeiro, RJ - Brazil Phone: +552131146776 Cellular: +55 $219947-7564$ lucasmed@ig.com.br

http://dx.doi.org/10.1590/1806-9282.60.01.009

Conflict of interest: none

\section{SUMMARY}

Objective: To assess the incidence rate and severity of depressive symptoms in different time points (12, 24 and 48 weeks) in Brazilian patients with HCV treated with PEG IFN plus ribavirin.

Methods: We conducted an observational prospective study using the Beck Depression Inventory (BDI) and the Center for Epidemiologic Studies Depression Scale (CES-D).

Results: Fifty patients were included. The assessments with either scale showed the highest score of depressive symptoms in the $24^{\text {th }}$ week of treatment; the mean BDI score before treatment was $6.5 \pm 5.3$ and the mean CES-D was $10.9 \pm 7.8$. After 24 weeks, the mean BDI was $16.1 \pm 10.2$ and mean CES-D was $18.6 \pm 13.0 ; 46 \%$ were diagnosed with depression according to combined BDI and CES-D scores. The somatic/psychomotor subscales were highly correlated with overall scale scores. Subjects with history of substance and alcohol abuse had higher risk for IFN-induced depression. Conclusion: Treatment with PEG IFN was associated with a high incidence rate of depressive symptoms in this sample of Brazilian patients, as measured by CES-D and BDI. Alcohol and substance abuse increase the risk of PEG IFN-induced depression.

Key words: $\mathrm{HCV}$, pegylated interferon alpha- $2 \mathrm{~b}$, interferon alpha, depression, hepatitis.

\section{INTRODUCTION}

Chronic hepatitis $\mathrm{C}$ is a major public health problem. About 150 million people are chronically infected with hepatitis $\mathrm{C}$ virus $(\mathrm{HCV})$, and more than 350000 people die every year from hepatitis C-related liver diseases. ${ }^{1}$ The $\mathrm{HCV}$ is commonly transmitted through exposure to infected blood, through the receipt of contaminated blood transfusions, blood products and organ transplants, and usage of contaminated syringes.

Combined therapy with pegylated interferon (PEG IFN) and ribavirin is the mainstay of hepatitis $C$ treatment $;{ }^{1}$ however, a high incidence of depressive symptoms is associated with the treatment with IFN ${ }^{2-6}$, which, in addition to the burden of psychiatric illness itself, causes a negative impact on both treatment adherence and quality of life..$^{3,7,8}$
Early diagnosis and treatment of depression are associated with better adherence to antiviral therapy; ${ }^{3}$ therefore, practical diagnosis and assessment tools are useful in non-psychiatric medical settings, in order to adequately treat this disorder.

The BDI has two subscales: somatic and affective. The affective subscale contains eight items: pessimism, past failures, guilt feelings, punishment feelings, self-dislike, selfcriticalness, suicidal thoughts or wishes, and worthlessness. The somatic subscale consists of the other thirteen items: sadness, loss of pleasure, crying, agitation, loss of interest, indecisiveness, loss of energy, change in sleep patterns, irritability, change in appetite, concentration difficulties, tiredness and/or fatigue, and loss of interest in sex. ${ }^{9}$ The CES-D scale is a short self-report scale designed to measure depres- 
sive symptoms in the general population. The items of the scale are symptoms associated with depression which have been used in previously validated longer scales. ${ }^{10}$

Some authors state that neurovegetative symptoms (e.g. fatigue, psychomotor slowing, changes in sleep and appetite) tend to occur early in treatment and persist, whilst more depression-specific symptoms (e.g. loss of interest or pleasure, depressed mood) develop later during thera$\mathrm{py}^{11}$. Accordingly, we have also measured the correlation between somatic subscales and the overall scale scores.

\section{Methods}

The present study aims at measuring the incidence rate of depressive symptoms in a sample of $50 \mathrm{HCV}$ -infected patients treated with pegylated interferon alpha (PEG IFN) plus ribavirin, in different time points, comparing pre-treatment with 12, 24 and 48 weeks of treatment, using the Beck Depression Inventory $(\mathrm{BDI})^{9}$ and the Center for Epidemiologic Studies Depression Scale (CES-D). ${ }^{10}$

We also assessed whether premorbid conditions, such as substance abuse and depression, and demographic characteristics (age, gender), were associated with a higher risk of depression. We conducted an observational prospective epidemiologic study with a convenience sample; subjects were consecutively included from April 2007 to February 2009. All the subjects were eligible to therapy with PEG IFN plus ribavirin and were under treatment at the Gastroenterology Outpatient Service, Gafrée and Guinle University Hospital, Rio de Janeiro, Brazil. The inclusion criteria of this study therefore represent the requirements to be submitted to treatment with PEG IFN plus ribavirin in our institution. The study was approved by the Gafrée and Guinle University Hospital Ethics Committee, and it was conducted in accordance with the Declaration of Helsinki (1975, revised in 1989). All the patients signed an informed consent before any data was collected. Since this was an observational study, all the patients followed their routine treatment, and any drug treatment, including use of antidepressant, was dictated by the judgment of treating physicians.

\section{Inclusion criteria:}

$\mathrm{HCV}$ infection, detected by the presence of HCV RNA, by polymerase chain reaction (Amplicor ${ }^{\circledR}$, Roche Diagnostics, Branchburg, NJ, USA) for more than 6 months;

- Age $\geq 18$ years old;

- Stable hepatic disease (serum bilirubin $<1.5 \mathrm{~g} / \mathrm{dL}$, RNI $<1.5$, serum albumin $>3.4 \mathrm{~g} / \mathrm{dL}$, platelets $>75,000$ cells $/ \mathrm{mm}^{3}$ and absence of ascites and hepatic encephalopathy);
- Biochemistry and hematological parameters: creatinin $<1.5 \mathrm{mg} / \mathrm{dL}$, hemoglobin $>13 \mathrm{~g} / \mathrm{dL}$ for men and $>12 \mathrm{~g} /$ $\mathrm{dL}$ for women, neutrophil count $>1,500$ cells $/ \mathrm{mm}^{3}$.

\section{Exclusion criteria}

- Co-infection with HIV;

- Co-infection with Hepatitis B virus (HBV);

- Presence of hepatocellular carcinoma;

- Substance and/or alcohol abuse in the last 6 months;

- Use of psychotropic medication in the last 6 months, including antidepressants, benzodiazepines, hypnotics, anticonvulsants, mood stabilizers, opioids, antiparkinsonian, antipsychotics and anticholinesterasics;

- Diagnosis of depression in the last 6 months.

\section{Pharmacotherapy}

All patients were treated with combined PEG IFN alpha-2b $(1.5 \mu \mathrm{g} / \mathrm{kg}$ subcutaneously, once weekly) plus ribavirin (750 to $1250 \mathrm{mg} /$ day, per oral). Genotypes 2 and 3 should receive treatment for 6 months and genotype 1 patients should be treated for 12 months.

\section{Assessments}

Patients were assessed with interviews using the BDI, version revised in $1979^{9,12}$ and the CES-D,${ }^{10}$ two self-rated scales, before starting pharmacotherapy, and after 12 and 24 weeks of treatment. An additional interview after 48 weeks was scheduled only for patients with genotype 1 . Although the scales were self-rated, the interviewer helped the respondents to make sure they understood the questions, by reading aloud the questions whenever necessary, as there was a high prevalence of illiteracy in our sample. The principal investigator (LPM), physician and well trained in the assessment tool, was the only interviewer.

We chose the BDI and the CES-D as assessment tools because our intention was to assess the depressive symptoms, instead of making a categorical diagnosis of depression; for this purpose, the choice of psychometric tools seemed to be more adequate.

Although our primary aim was to assess the frequency and severity of depressive symptoms, we also measured the incidence rate of PEG IFN-induced depression, considering the CES-D score $\geq 15$ (for subjects with CES-D score $<15$ before treatment) or an increase of $\geq 1 \mathrm{SD}$ in comparison with the group mean at the moment of the evaluation (for subjects with CES-D $\geq 15$ before treatment with PEG IFN). The BDI cut-off adopted for depression was a score $\geq 10$ (for patients with score $<10$ before treatment, i.e., with no depression), or an increase in the mean score indicating a change for a higher level of severity of symptoms 
$(10-18$ points $=$ mild to moderate depression $; 19-29=$ moderate to severe depression and $30-63=$ severe depression). ${ }^{13}$

\section{Statistics}

The SPSS (Statistical Package for the Social Sciences) version 13 was used for analyses. Fischer exact test was used to compare categorical variables. Friedman test and Wilcoxon test (Bonferroni corrected) were performed to compare mean depressive symptoms in distinct time points; Spearman correlation coefficient was used to assess correlations between subscales and overall scale scores; $\mathrm{c}^{2}$ McNemar test was performed to compare the correlation between $\mathrm{BDI}$ and CES-D. We included in the analyses the data of all patients while they remained under treatment. Results from different time points were compared after Bonferroni correction, to adjust the variation in number of subjects throughout the study.

\section{Results}

Fifty subjects were included. Demography and genotype characteristics are described in Table 1. By random circumstances, the same proportion of males and females occurred in our sample. The overall mean BDI score before treatment was $6.5 \pm 5.3$ and the mean CES-D was $10.9 \pm 7.8$.

\section{TABLE 1 Demography and genotype characteristics}

\begin{tabular}{l|l|l} 
Characteristic & $\mathrm{N}(50)$ & \\
\hline Age, years (mean $\pm \mathrm{SD})$ & $50( \pm 9.0)$ & \\
\hline Age, years (range) & $25-66$ & \\
\hline Male (N, \%) & $25(50.0 \%)$ & \\
\hline Female (N, \%) & $25(50.0 \%)$ & \\
\hline Genotype & & $\mathrm{Cl} 95 \%$ \\
\hline Genotype 1 (N,\%) & $41(82.0 \%)$ & $69.5 \%-90.9 \%$ \\
\hline Genotype 2 (N,\%) & $2(4.0 \%)$ & $0.7 \%-12.6 \%$ \\
\hline Genotype 3 (N,\%) & $7(14.0 \%)$ & $6.3 \%-25.7 \%$ \\
\hline SD: standard deviation & &
\end{tabular}

The total scores of depressive symptoms measured by either BDI or CES-D increased compared to the baseline.

The highest scores were observed at week 24, with both CES-D and BDI (Table 2), regardless of the genotype.

One patient abandoned treatment due to depression with psychotic symptoms, which did not remit with antidepressant and antipsychotic drugs. After 12 weeks, 2 patients were considered treatment failure and interrupted the antiviral treatment. After 24 weeks, other 11 patients were considered treatment failure and stopped antiviral treatment.

The overall incidence rate of PEG IFN-induced depression was $64 \%(\mathrm{~N}=32)$ with BDI and $52 \%(\mathrm{~N}=26)$ with CES-D; 46\% ( $\mathrm{N}=23)$ had PEG IFN-induced depression by either BDI or CES-D. Regarding demographic characteristics, the incidence was similar in males and females, and there was no influence of age or ethnicity; the incidence of PEG IFN-induced depression was higher in subjects with history of alcohol and other substances' abuse (Table 3). Higher scores before treatment ("depression positivity") were not predictive of depression during treatment, according to CES-D ( $p>0.05$ in all time points); however, higher BDI scores correlated with depression during PEG IFN treatment $(\mathrm{p}=0.001$ in 12 weeks, $\mathrm{p}<0.001$ in 24 weeks and $\mathrm{p}=0.008$ in 28 weeks).

The somatic/psychomotor subscale scores were highly correlated with the overall scale scores: Spearman correlation coefficients ranged from 0.831 to 0.955 for CES-D $(p<0.001)$ and from 0.705 to 0.872 for the BDI $(p<0.001)$ in the different time points of the study. CES-D and BDI were also highly correlated, with a Spearman correlation coefficient close to 1 throughout the observation period.

TABLE 2 Mean BDI and CES-D total scores before treatment and after 12, 24 and 48 weeks by genotype. Only genotype 1 patients were assessed at week 48

\begin{tabular}{|c|c|c|c|c|c|c|c|c|}
\hline \multirow[t]{2}{*}{ Genotype } & \multicolumn{4}{|c|}{ Genotype 1} & \multicolumn{4}{|c|}{ Genotypes 2 and 3} \\
\hline & $N$ & Mean \pm SD & Range & $P$ value (vs pre-treatment) & $\mathrm{N}$ & Mean \pm SD & Range & *P value (vs pre-treatment) \\
\hline \multicolumn{9}{|l|}{ BDI } \\
\hline Pretreatment & 41 & $6.7 \pm 4.9$ & $0-23.0$ & & 9 & $5.8 \pm 7.4$ & $0-24.0$ & \\
\hline 12 weeks & 41 & $15.0 \pm 10.7$ & $3.0-46.0$ & $<0.001$ & 9 & $14.2 \pm 8.8$ & $5.0-32.0$ & 0.086 \\
\hline 24 weeks & 38 & $16.1 \pm 10.6$ & $2.0-41.0$ & $<0,001$ & 9 & $15.9 \pm 9.1$ & $3.0-30.0$ & 0.030 \\
\hline 48 weeks & 22 & $13.1 \pm 9.5$ & $1.0-30.0$ & 0.001 & - & - & - & - \\
\hline \multicolumn{9}{|l|}{ CES-D } \\
\hline Pre-treatment & 41 & $11.3 \pm 7.8$ & $0-28.0$ & & 9 & $9.1 \pm 7.9$ & $2.0-24$ & \\
\hline 12 weeks & 41 & $17.2 \pm 12.1$ & $0-47.0$ & 0.005 & 9 & $19.0 \pm 14.0$ & $7.0-45.0$ & 0.066 \\
\hline 24 weeks & 38 & $18.3 \pm 12.9$ & $1.0-47.0$ & 0.004 & 9 & $19.6 \pm 14.1$ & $1.0-39.0$ & 0.033 \\
\hline 48 weeks & 22 & $15.5 \pm 13.1$ & $0-40.0$ & 0.172 & - & - & - & - \\
\hline
\end{tabular}


TABLE 3 Demographic characteristics and PEG IFNinduced depression ${ }^{\mathrm{a}}$ (CES-D and BDI)

\begin{tabular}{|c|c|c|c|c|}
\hline \multirow[t]{2}{*}{ Characteristic } & \multirow[t]{2}{*}{ Total } & \multicolumn{2}{|c|}{$\begin{array}{l}\text { PEG IFN induced } \\
\text { depression? }\end{array}$} & \multirow[t]{2}{*}{ p-value* } \\
\hline & & No & Yes & \\
\hline & $n$ & $\mathrm{n}(\%)$ & $\mathrm{n}(\%)$ & \\
\hline \multicolumn{5}{|l|}{ Gender } \\
\hline Male & 25 & $12(48.0)$ & $13(52.0)$ & 0.395 \\
\hline Female & 25 & $15(60.0)$ & $10(40.0)$ & \\
\hline \multicolumn{5}{|l|}{ Age (yrs) } \\
\hline $25-49$ & 23 & $13(56.5)$ & $10(43.5)$ & 0.741 \\
\hline $50-66$ & 27 & $14(51.9)$ & $13(48.1)$ & \\
\hline \multicolumn{5}{|l|}{ Ethnicity } \\
\hline White & 29 & $16(55.2)$ & $13(44.8)$ & 1.00 \\
\hline Non White & 21 & $11(52.4)$ & $10(47.6)$ & \\
\hline \multicolumn{5}{|c|}{ Hepatitis C etiology } \\
\hline Unknown & 19 & $11(57.9)$ & $8(42.1)$ & 0.773 \\
\hline Known & 31 & $16(51.6)$ & $15(48.4)$ & \\
\hline \multicolumn{5}{|l|}{ Metavir } \\
\hline$<2$ & 9 & $5(55.6)$ & $4(44.4)$ & 1.00 \\
\hline$>2$ & 37 & $20(54.1)$ & $17(45.9)$ & \\
\hline \multicolumn{5}{|l|}{ Retreatment } \\
\hline No & 41 & $22(53.7)$ & $19(46.3)$ & 1.00 \\
\hline Yes & 9 & $5(55.6)$ & $4(44.4)$ & \\
\hline \multicolumn{5}{|c|}{ Antidepressant use } \\
\hline No & 41 & $25(61.0)$ & $16(39.0)$ & 0.062 \\
\hline Yes & 9 & $2(22.2)$ & $7(77.8)$ & \\
\hline \multicolumn{5}{|l|}{ Genotype } \\
\hline 1 & 41 & $22(53.7)$ & $19(46.3)$ & 1.00 \\
\hline $2 / 3$ & 9 & $5(55.6)$ & $4(44.4)$ & \\
\hline \multicolumn{5}{|l|}{ Alcohol abuse } \\
\hline No & 45 & $27(60.0)$ & $18(40.0)$ & 0.016 \\
\hline Yes & 5 & $0(0.0)$ & $5(100.0)$ & \\
\hline \multicolumn{5}{|c|}{ Substance abuse } \\
\hline No & 45 & $27(60.0)$ & $18(40.0)$ & 0.016 \\
\hline Yes & 5 & $0(0.0)$ & $5(100.0)$ & \\
\hline \multicolumn{5}{|l|}{$\begin{array}{l}\text { History of } \\
\text { depression }\end{array}$} \\
\hline No & 41 & $25(61.0)$ & $16(39.0)$ & 0.062 \\
\hline Yes & 9 & $2(22.2)$ & $7(77.8)$ & \\
\hline
\end{tabular}

\section{Discussion}

The increase in depressive symptoms caused by PEG IFN observed in our sample corroborates the findings in the literature. ${ }^{2-6,8,14,15} \mathrm{~A}$ hypothesis has been raised that pegylated preparations of IFN could be associated with less neuropsychiatric burden, including depression ${ }^{5,16-18}$, but pros- pective studies using validated screening tools have shown a high incidence of depression with PEG IFN as well. ${ }^{3,5,19}$ Presently, there is considerable variability of the frequency and extent of IFN-induced depression reported in different cohorts of patients, due to different study populations, treatment regimens, methodological approaches, arbitrary or poorly defined choice of screening instruments for depression, and different criteria for clinically relevant depression (cut-off criteria). ${ }^{11} \mathrm{~A}$ recent meta-analysis showed that IFN-induced depression is $25 \%$ in 24 weeks and $28 \%$ in 48 weeks, and the risk factors are: high baseline symptoms level, female gender, low educational level and history of depressive episodes. ${ }^{20} \mathrm{In}$ our sample, the observed incidence was $46 \%$, with peak of symptoms occurring at week 24 . Pavlovic et al. ${ }^{15}$, in a 24-week prospective study, observed the highest score of symptoms at week 12 and also noticed that self-assessment scale was equally reliable as observer-based assessments of depressive symptoms. Although the peak of symptoms in our sample occurred in 24 weeks, at week 12 there was also a significant increase in depressive symptoms compared to the baseline. The use of two scales increased the sensitivity and specificity of the assessments and allowed a comparison with a wider range of data from the literature. Treatment with IFN seems to have an overall impact in all dimensions of depression, as the somatic and mood subscales were equally affected.

Different from other studies, ${ }^{5,15,21}$ our data showed a correlation between history of substance/alcohol abuse and IFN-induced depression. On the other hand, a correlation with gender and previous depressive episodes was not observed, contrary to findings from other authors. ${ }^{20}$

Our study is limited by the small sample size and the lack of a control group. However, it corroborates the data in the literature, and provides additional information regarding development of symptoms and the use of CES-D and BDI as screening and assessment tools. The BDI seems to be more sensitive to changes during treatment period. As depression affects the quality of life and adherence to treatment, $, 3,8$ it is fundamental to have strategies to deal with this condition. Although prophylaxis of IFN-induced depression with antidepressants remains controversial, ${ }^{22}$ pharmacological treatment of depression after its onset has proven effective and beneficial. ${ }^{3,23}$

\section{Conclusions}

In conclusion, there is a high incidence rate of PEG IFN-induced depression and depressive symptoms measured by both BDI and CES-D. The somatic/psychomotor subscales were highly correlated with the overall scale scores. Subjects with history of substance and alcohol abuse had higher risk for IFN-induced depression. 


\section{Resumo}

Depressão induzida por interferon em pacientes com hepatite C: um estudo epidemiológico.

Objetivo: Avaliar a incidência e a gravidade de sintomas depressivos em diferentes intervalos (12, 24 e 48 semanas) em pacientes brasileiros com HCV tratados com PEG IFN mais ribavirina.

Métodos: Foi feito um estudo prospectivo observacional, usando o Inventário de Depressão de Beck (BDI) e a Escala de Rastreamento Populacional de Depressão (CES-D). Resultados: Foram incluídos 50 pacientes. As avaliações com ambas as escalas mostraram os maiores escores de depressão na $24^{a}$ semana de tratamento; o escore BDI médio antes do tratamento foi de $6,5 \pm 5,3$ e o CES-D foi 10,9 $\pm 7,8$. Após 24 semanas, o BDI médio foi 16,1 $\pm 10,2$ e o CES-D foi 18,6 $\pm 13,0$; de acordo com os escores combinados BDI e CES-D, 46\% receberam diagnóstico de depressão. As subescalas somática e psicomotora tiveram alta correlação. Indivíduos com história de abuso de substâncias e de álcool apresentaram maior risco de desenvolver depressão por PEG IFN.

Conclusão: O tratamento com PEG IFN associou-se a uma alta incidência de sintomas depressivos nessa população de pacientes brasileiros, de acordo com a BDI e CES-D. Abuso de álcool e substâncias aumentam o risco de depressão induzida por PEG IFN.

Unitermos: $\mathrm{HCV}$, interferon peguilado alfa-2b, interferon alfa, depressão, hepatite.

\section{References}

1. World Health Organizartion (WHO). Hepatitis C. Fact sheet n.164. Available from: http://www.who.int/mediacentre/factsheets/fs164/en/index.html\#.

2. Horikawa N, Yamazaki T, Izumi N, Uchihara M. Incidence and clinical course of major depression in patients with chronic hepatitis type $\mathrm{C}$ undergoing interferon-alpha therapy: a prospective study. Gen Hosp Psychiatry. 2003;25:34-8.

3. Martin-Santos R, Diez-Quevedo C, Castellvi P, Navines R, Miquel M, Masnou H, Soler A, Ardevol M, Garcia F, Galeras JA, Planas R, Sola R. De novo depression and anxiety disorders and influence on adherence during peginterferon-alpha-2a and ribavirin treatment in patients with hepatitis C. Aliment Pharmacol Ther. 2008;27:257-65.

4. Quarantini LC, Bressan RA, Galvao A, Batista-Neves S, Parana R, MirandaScippa A. Incidence of psychiatric side effects during pegylated interferonalpha retreatment in nonresponder hepatitis $\mathrm{C}$ virus-infected patients. Liver Int. 2007;27:1098-102.
5. Raison CL, Borisov AS, Broadwell SD, Capuron L, Woolwine BJ, Jacobson IM, Nemeroff CB, Miller AH. Depression during pegylated interferon-alpha plus ribavirin therapy: prevalence and prediction. J Clin Psychiatry. 2005;66:41-8.

6. Reichenberg A, Gorman JM, Dieterich DT. Interferon-induced depression and cognitive impairment in hepatitis $C$ virus patients: a 72 week prospective study. AIDS. 2005;19(Suppl 3):S174-8.

7. Batista-Neves S, Quarantini LC, Galvao-de Almeida A, Cardeal M, Lacerda AL, Parana R, Reis de-Oliveira I, Bressan RA, Miranda-Scippa A. Impact of psychiatric disorders on the quality of life of brazilian HCV-infected patients. Braz J Infect Dis. 2009;13:40-3.

8. Dan AA, Martin LM, Crone C, Ong JP, Farmer DW, Wise T, Robbins SC, Younossi ZM. Depression, anemia and health-related quality of life in chronic hepatitis C. J Hepatol. 2006;44:491-8.

9. Beck AT, Ward CH, Mendelson M, Mock J, Erbaugh J. An inventory for measuring depression. Arch Gen Psychiatry. 1961;4:561-71.

10. Radloff LS. The CES-D scale: a self report depression scale for research in the general population. Appl Psychol Meas. 1977:385-401.

11. Schafer A, Wittchen HU, Seufert J, Kraus MR. Methodological approaches in the assessment of interferon-alfa-induced depression in patients with chronic hepatitis C - a critical review. Int J Methods Psychiatr Res. 2007;16:186-201.

12. Beck AT, Rush AJ, Shaw BF, Emery G. Cognitive therapy of depression. New York: Guilford; 1979.

13. Beck AT, Steer RA, Garbin MG. Psychometric properties of the Beck Depression Inventory: twenty-five years of evaluation. Clin Psychol Rev. 1988;8:77-100

14. Castera L, Zigante F, Bastie A, Buffet C, Dhumeaux D, Hardy P. Incidence of interferon alfa-induced depression in patients with chronic hepatitis $\mathrm{C}$. Hepatology. 2002;35:978-9.

15. Pavlovic Z, Delic D, Maric NP, Vukovic O, Jasovic-Gasic M. Depressive symptoms in patients with hepatitis $C$ treated with pegylated interferon alpha therapy: a 24-week prospective study. Psychiatr Danub. 2011;23:370-7.

16. Bernstein D, Kleinman L, Barker CM, Revicki DA, Green J. Relationship of health-related quality of life to treatment adherence and sustained response in chronic hepatitis C patients. Hepatology. 2002;35:704-8.

17. Fried MW, Shiffman ML, Reddy KR, Smith C, Marinos G, Goncales FL, Jr., Haussinger D, Diago M, Carosi G, Dhumeaux D, Craxi A, Lin A, Hoffman J, Yu J. Peginterferon alfa-2a plus ribavirin for chronic hepatitis C virus infection. N Engl J Med. 2002;347:975-82.

18. Manns MP, McHutchison JG, Gordon SC, Rustgi VK, Shiffman M, Reindollar R, Goodman ZD, Koury K, Ling M, Albrecht JK. Peginterferon alfa-2b plus ribavirin compared with interferon alfa- $2 \mathrm{~b}$ plus ribavirin for initial treatment of chronic hepatitis C: a randomised trial. Lancet. 2001;358:958-65.

19. Neri S, Pulvirenti D, Bertino G. Psychiatric symptoms induced by antiviral therapy in chronic hepatitis C: comparison between interferon-alpha-2a and interferon-alpha-2b. Clin Drug Investig. 2006;26:655-62.

20. Udina M, Castellvi P, Moreno-Espana J, Navines R, Valdes M, Forns X, Langohr K, Sola R, Vieta E, Martin-Santos R. Interferon-induced depression in chronic hepatitis C: a systematic review and meta-analysis. J Clin Psychiatry. 2012;73:1128-38

21. Hauser P, Khosla J, Aurora H, Laurin J, Kling MA, Hill J, Gulati M, Thornton AJ, Schultz RL, Valentine AD, Meyers CA, Howell CD. A prospective study of the incidence and open-label treatment of interferon-induced major depressive disorder in patients with hepatitis C. Mol Psychiatry. 2002;7:942-7.

22. Galvao-de Almeida A, Guindalini C, Batista-Neves S, de Oliveira IR, MirandaScippa A, Quarantini LC. Can antidepressants prevent interferon-alphainduced depression? A review of the literature. Gen Hosp Psychiatry. 2010;32:401-5.

23. Kraus MR, Schafer A, Schottker K, Keicher C, Weissbrich B, Hofbauer I, Scheurlen $\mathrm{M}$. Therapy of interferon-induced depression in chronic hepatitis $\mathrm{C}$ with citalopram: a randomised, double-blind, placebo-controlled study. Gut. 2008;57:531-6. 